\title{
PENGARUH LINGKUNGAN KERJA TERHADAP KINERJA CUSTOMER CARE YANG MENERAPKAN WORK FROM HOME DI BIDANG KESEHATAN
}

\author{
Irene Melati Carlita, Arshad Rahmanidal dan Sedarmayanti \\ Universitas Kristen Maranatha Bandung Jawa Barat, Indonesia \\ Email: irenecarlita@gmail.com, arshadrahmanidal@gmail.com dan \\ sedarmayanti@gmail.com
}

\section{Abstract}

In this current pandemic situation, many companies in Indonesia implementing work from home to support physical distancing program to prevent the spread of COVID-19. This study using data analysis methods named multiple linear regression to determine the effect of independent variables, Physical Environment $\left(X_{1}\right)$ and Non-Physical Environment $\left(X_{2}\right)$ on Employee Performance $(Y)$ on 54 customer care in one of Health Sector X. The hypothesis in this study also use T test and $F$ test to see the effect of two independent variables on the dependent variable either partially or simultaneously. From the results of the research, it shows that these two variables simultaneously has $29.6 \%$ significant effect on employee performance. This explains that the conditions workplace, and the relationship between employee with supervisors and colleagues will affect the performance of customer care, either directly or indirectly. Partially, the physical environment itself has an effect on $27.46 \%$ of employee performance. Meanwhile, the non-physical environment does not effect on employee performance.

Keywords: work environment; employee performance; customer care

\begin{abstract}
Abstrak
Pada situasi pandemi saat ini banyak perusahaan di Indonesia yang turut menerapkan kerja jarak jauh untuk mendukung program physical distancing mencegah penyebaran COVID-19. Penelitian ini diolah menggunakan regresi linier berganda untuk mengetahui pengaruh variabel Lingkungan Fisik $\left(\mathrm{X}_{1}\right)$ dan Lingkungan Non-Fisik $\left(\mathrm{X}_{2}\right)$ terhadap Kinerja Karyawan (Y) pada 54 orang customer care di Bidang Kesehatan X. Hipotesis pada penelitian ini menggunakan Uji $\mathrm{T}$ dan Uji $\mathrm{F}$ untuk melihat pengaruh dua variabel independen terhadap variabel dependen baik secara parsial atapun simultan. Dari hasil penelitian yang sudah dilakukan, menunjukkan bahwa kedua variabel ini secara simultan berpengaruh signifikan sebesar 29,6\% terhadap Kinerja Karyawan. Hal ini menjelaskan bahwa keadaan yang terdapat di sekitar tempat kerja dan hubungan antara bawahan dengan atasan dan rekan kerja akan mempengaruhi kinerja customer care baik secara langsung ataupun tidak langsung. Secara parsial, lingkungan fisik berpengaruh $27,46 \%$ terhadap kinerja karyawan. Sedangkan lingkungan non-fisik tidak berpengaruh sebesar terhadap kinerja karyawan.
\end{abstract}


Kata Kunci: lingkungan kerja; kinerja karyawan; customer care

\section{Pendahuluan}

Pada akhir tahun 2019 hingga awal tahun 2020 hampir seluruh negara didunia digemparkan dan harus berhadapan dengan suatu wabah yakni virus korona. Coronavirus termasuk dalam jenis virus yang dapat menyebabkan penyakit pada hewan dan juga manusia. Pada manusia, beberapa jenis dari coronavirus dapat menyebabkan infeksi pada saluran pernapasan mulai dari flu biasa hingga penyakit yang lebih parah seperti Middle East Respiratory Syndrome (MERS) dan Severe Acute Respiratory Syndrome (SARS). Virus korona yang paling baru ditemukan dapat menyebabkan penyakit virus korona COVID-19. Gejala-gelaja yang paling sering muncul dari orang yang terinfeksi COVID-19 antara lain demam, batuk kering, serta kelelahan. Banyak orang yang dapat sembuh dari penyakit ini tanpa memerlukan perawatan di rumah sakit. Namun, sekitar 1 dari setiap 5 orang yang terjangkit penyakit COVID-19 dapat mengalami kesulitan bernapas hingga menderita sakit parah sehingga membutuhkan perawatan rumah sakit.

Penyakit ini dapat menyebar dari orang ke orang melalui tetesan kecil dari hidung atau mulut, yang keluar saat penderita COVID-19 batuk, bersin, atau berbicara. Tetesan yang menempel/mendarat pada meja, gagang pintu, dan pegangan tangan yang nantinya dapat ter-transfer kepada orang lain yang melakukan kontak dengan penderita COVID19. Apabila orang yang telah melakukan kontak kemudian menyentuh mata, hidung, atau mulut maka kemungkinan besar orang tersebut dapat terinfeksi. Inilah alasan pentingnya untuk mencuci tangan secara teratur dengan sabun dan air atau membersihkan tangan dengan antiseptik berbasis alkohol serta untuk menjaga jarak setidaknya 1 meter dari orang lain. Pada tanggal 18 September 2020 dari pencatatan WHO saat ini terdapat 216 negara yang terinfeksi dengan jumlah kasus yang terkonfirmasi sebanyak 30.055.710, dan jumlah kematian yang mencapai 943.433 orang. Sedangkan di Indonesia sendiri pada tanggal 18 September 2020 konfirmasi kasus sebanyak 236.519 orang (Organization, 2020).

Untuk mencegah terjadinya penyebaran COVID-19 lebih luas, hampir diseluruh dunia sepakat untuk melaksanakan pembatasan gerak atau yang disebut physical distancing hingga pelaksanaan lockdown oleh suatu negara. Akibat dilaksanakannya hal physical distancing, banyak perusahaan yang menerapkan Work From Home (WFH) kepada karyawannya untuk mendukung jalannya pembatasan gerak mencegah penyebaran lebih luas sekaligus mempertahankan keberlangsungan hidup dan kerja perusahaan. Menurut Wikipedia, Work From Home atau Telecommuting adalah pengaturan kerja dimana karyawan tidak perlu berpergian atau melakukan perjalanan ke tempat kerja yang berada dipusat, salah satunya seperti gedung kantor. Karyawan yang bekerja dari rumah atau yang tidak perlu datang ke tempat kerja pusat dapat mengurangi waktu perjalanan dan waktu terjebak dalam kemacetan sehingga hal ini dilihat sebagai bentuk peningkatan kualitas hidup pekerja. Selain itu, teleworking juga dapat mempermudah karyawan untuk menyeimbangkan waktu kerja mereka dengan 
kehidupan pribadinya seperti merawat anak-anak atau anggota keluarga lain yang berada di rumah.

Lingkungan kerja adalah sesuatu yang ada di sekitar para pekerja dan memengaruhi dirinya (karyawan) dalam menjalankan tugas-tugas yang dibebankan (Nitisemito, 1982). Menurut (Mangkunegara, 2016) lingkungan kerja meliputi semua aspek-aspek seperti; fisik, psikologis, dan peraturan kerja yang dapat mempengaruhi kepuasan kerja, pencapaian, dan produktivitas karyawan. Lingkungan fisik menurut (Sedarmayanti, 2011) memiliki arti yakni, semua keadaan yang terdapat di sekitar tempat kerja, yang akan mempengaruhi karyawan baik secara langsung ataupun tidak langsung. Terdapat beberapa faktor yang dapat mempengaruhi terbentuknya suatu kondisi lingkungan kerja antara lain; penerangan/cahaya, temperatur, kelembaban, sirkulasi udara, kebisingan, getaran mekanis, bau-bauan, tata warna, dekorasi, musik, dan keamanan di lingkungan tempat bekerja. Faktor-faktor ini dapat mempengaruhi kemampuan manusia (karyawan),

Selain lingkungan kerja fisik terdapat lingkungan kerja non fisik, berupa suasana kerja yang harmonis, dimana terjadi hubungan atau komunikasi antara bawahan dengan atasan (hubungan vertikal) dan hubungan antar sesama karyawan (hubungan horizontal) (Sedarmayanti, 2013).

Dalam situasi saat ini tujuan utama dari penerapan Work From Home adalah untuk melakukan pencegahan terhadap penyebaran virus korona di Indonesia yang saat ini dapat dikatakan cukup pesat. Hal ini juga dikaitkan dengan ketentuan Undang-Undang Ketenagakerjaan Nomor 13 tahun 2003 dimana setiap pekerja/buruh mempunyai hak untuk memperolah perlindungan atas keselamatan dan kesehatan kerja. Sehingga pelaksanaan Work From Home diharapkan dapat melindungi pekerja dari penyebaran COVID-19. Langkah-langkah pencegahan yang dapat dilakukan menurut SE Disnakertrans dan Energi DKI dikelompokkan menjadi tiga kategori, yaitu:

a. Untuk sementara waktu perusahaan dapat menghentikan seluruh kegiatan usahanya.

b. Perusahaan untuk sementara waktu dapat mengurangi sebagian kegiatan usahanya (termasuk : sebagian karyawan, waktu, dan fasilitas operasionalnya)

c. Perusahaan yang tidak dapat menghentikan kegiatan usahanya, mengingat kepentingan langsung yang berhubungan dengan pelayanan kesehatan, kebutuhan bahan-bahan pokok, dan bahan bakar minyak.

Pada penelitian ini, yang menjadi subjek penelitian adalah customer care di bidang kesehatan yang tetap harus bekerja ditengah dipandemi mengingat bidang kerjanya menyangkut kepentingan orang banyak. Karyawan customer care bidang kesehatan ini berjumlah kurang lebih 80 orang dan hampir $50 \%$ dari jumlah tersebut sudah melaksanakan Work From Home dari bulan Maret hingga September. Customer care bidang kesehatan ini memiliki tugas yakni melayani keluhan pengguna sesuai ketentuan, guna memenuhi kebutuhan dengan tepat sasaran dan tepat waktu dan memberikan pelayanan berupa informasi yang dibutuhkan kepada konsumen. 
Dalam pelaksanaan Work From Home para karyawan yang terbiasa bekerja di gedung kantor dan menggunakan fasilitas kantor seperti laptop atau komputer dan fasilitas internet, harus melaksanakan kegiatan bekerja dari tempat tinggal (rumah atau kos). Walaupun di zaman sekarang ini harapannya semua orang sudah terbiasa dan mahir menggunakan teknologi namun dalam pelaksanaan Work From Home masih ditemukan beberapa kendala dan proses adaptasi yang masih dibutuhkan. Sama seperti yang dialami customer care bidang kesehatan ini, saat melaksanakan Work From Home terdapat beberapa kendala yang terjadi seperti kondisi kamar kos yang tidak nyaman akibat penerangan yang kurang terang, sirkulasi udara kamar kosan yang kurang baik, suara bising karena banyaknya anggota keluarga di rumah, dan kurangnya fasilitas yang memadai untuk melaksanakan pekerjaan. Keadaan lingkungan fisik ini memberikan rasa tidak nyaman bagi karyawan untuk melaksanakan pekerjannya. Selain lingkungan fisik, karyawan customer care bidang kesehatan ini juga mengalami kendala ketika harus berkomunikasi dengan atasan sehingga apabila terdapat keluhan yang perlu ditindaklanjuti lebih lanjut, tidak bisa langsung diproses secara langsung namun dibutuhkan waktu yang lebih lama.

Keadaan lingkungan kerja yang dipaparkan sebelumnya dapat memengaruhi kinerja karyawan dalam bekerja. Kinerja merupakan hasil kerja seorang pekerja, sebuah proses manajemen atau suatu organisasi secara keseluruhan, dimana hasil kerja tersebut harus dapat ditunjukkan buktinya secara konkrit dapat diukur (dibandingkan dengan standar yang telah ditentukan) (Sedarmayanti, 2017). Menurut Mitchell dalam buku (Sedarmayanti, 2016) dimensi kinerja karyawan terdiri dari kualitas kerja, kehadiran dan ketepatan waktu, inisiatif, kemampuan, dan komunikasi.

Penelitian ini bertujuan untuk mengetahui dan menjelaskan bagaimana variabel lingkungan kerja fisik dan non-fisik secara simultan ataupu secara parsial berpengaruh terhadap kinerja karyawan pada karyawan customer care bidang kesehatan X.

\section{Metode Penelitian}

Penelitian dalam artikel ini dilakukan dengan pendekatan kuantitatif dan menggunakan causal explanatory yang merupakan penelitian dengan menjelaskan bagaimana suatu variabel memengaruhi atau "bertanggung jawab" atas perubahan yang terjadi pada variabel lain (Cooper \& Schindler, 2006). Teknik analisis data yang akan digunakan adalah:

a. Analisis Deskriptif, digunakan untuk menggambarkan karakteristik data sebagaimana adanya serta menyusun distribusi frekuensi dengan menggunakan data dari kuisioner. Kemudian dari skor yang diperoleh, dilakukan analisis untuk mengungkapkan fenomena dari variabel penelitian.

b. Regresi Liner Berganda, merupakan suatu metode statistik yang digunakan untuk mengetahui hubungan fungsional antara variabel independen (bebas) dengan variabel dependen (terkait). Dengan rumus persamaan sebagai berikut:

$Y=a+b_{1} x_{1}+b_{2} x_{2} \ldots \ldots \ldots+b_{n} x_{n}+e$ 
Irene Melati Carlita, Arshad Rahmanidal dan Sedarmayanti

Keterangan:

$\mathrm{Y}=$ variabel dependen (kinerja karyawan)

A $\quad=$ konstanta, nilai tetap dari Y jika $x_{1} x_{2}=0$

$b_{1} b_{2} \quad=$ koefisien variabel independen

$x_{1} \quad=$ variabel bebas (Lingkungan kerja fisik)

$x_{2} \quad=$ variabel bebas (Lingkungan kerja non-fisik)

e $\quad=$ standard error

c. Uji F digunakan untuk menguji tingkat signifikasi dari pengaruh variabel indepeden secara bersama-sama (simultan) terhadap variabel dependen. Uji F ini dilaksanakan dengan cara membandingkan $\mathrm{F}$ hitung dari $\mathrm{F}$ tabel $\mathrm{x} F$ hitung dilihat dari hasil pengolahan data bagian Anova.

d. Uji t digunakan untuk menguji tingkat signifikasi pengaruh variabel independen secara parsial terhadap variabel dependen. Dengan uji $t$, nilai $t$ hitung dan nilai $t$ tabel akan dibandingkan.

Hipotesis yang diuji, $\mathrm{H}_{0}$ : Tidak ada hubungan linier antara variabel independen dan variabel dependen dan $\mathrm{H}_{1}$ : Ada hubungan linier antara variabel independen dan variabel dependen.

Populasi yang digunakan dalam penelitian ini adalah customer care di Bidang Kesehatan X. Dalam penelitian ini, pengambilan data akan dilakukan kepada customer care di Bidang Kesehatan X yang melaksanakan Work From Home terhitung Maret 2020. Diantaranya, pengambilan data akan dilakukan kepada sebanyak 54 orang yang menjalani WFH dari 80 orang karyawan. Menurut Sugiyono, populasi adalah wilayah generalisasi yang terdiri atas objek/subjek yang mempunyai kualitas dan karakteristik tertentu yang diterapkan oleh peneliti untuk dipelajari dan kemudian ditarik kesimpulannya.

Instrumen penelitian yang digunakan disusun oleh peneliti. Variabel lingkungan kerja fisik disusun dengan 11 indikator (penerangan, temperatur, kelembaban, sirkulasi udara kebisingan, getara mekanis, bau, tata warna, dekorasi ruang, musik, dan keamanan) dan lingkungan kerja non-fisik disusun dengan 2 indikator (hubungan karyawan dengan atasan dan hubungan kerja sesama rekan kerja). Variabel kinerja karyawan disusun berdasarkan 5 dimensi (kualitas kerja, ketepatan waktu, inisiatif, kemampuan, dan komunikasi). Instrumen penelitian berjumlah total 27 item yang disebarkan dalam bentuk kuisioner dan diukur menggunakan skala likert lima, dari 1 (sangat tidak setuju) hingga 5 (sangat setuju).

\section{Hasil dan Pembahasan}

\section{a. Uji Instrumen Penelitian (Uji Validitas dan Uji Reliabilitas)}

Menurut (Soekanto, 2007) validitas dijelaskan sebagai derajat untuk menunjukkan ketepatan antara data yang sesungguhnya terjadi pada objek dengan data yang peneliti kumpulkan. Koefisien antara item dengan total item $\geq 0,3$ maka 
item akan dinyatakan valid, dan item dengan nilai korelasi dibawah 0,3 dinyatakan tidak valid.

Tabel 1

Hasil Uji Validitas

\begin{tabular}{ccccc}
\hline & \multicolumn{3}{c}{ Pearson Correlation } & \multirow{2}{*}{ Keterangan } \\
\cline { 2 - 3 } LF1 & 0.586 & & & \\
\hline LF2 & 0.593 & & Valid \\
\hline LF3 & 0.730 & & & Valid \\
\hline LF4 & 0.343 & & & Valid \\
\hline LF5 & 0.588 & & Valid \\
\hline LF6 & 0.552 & & & Valid \\
\hline LF7 & 0.540 & & & Valid \\
\hline LF8 & 0.509 & & & Valid \\
\hline LF9 & 0.481 & & & Valid \\
\hline LF10 & 0.410 & & & Valid \\
\hline LF11 & 0.683 & & & Valid \\
\hline LNF1 & & 0.665 & & Valid \\
\hline LNF2 & & 0.758 & & Valid \\
\hline LNF3 & 0.855 & & Valid \\
\hline LNF4 & & 0.767 & & Valid \\
\hline KK1 & & & 0.622 & Valid \\
\hline KK2 & & & 0.743 & Valid \\
\hline KK3 & & & 0.573 & Valid \\
\hline KK4 & & & 0.621 & Valid \\
\hline KK5 & & & 0.625 & Valid \\
\hline KK6 & & & 0.666 & Valid \\
\hline KK7 & & & 0.717 & Valid \\
\hline KK8 & & 0.686 & Valid \\
\hline KK9 & & & 0.730 & Valid \\
\hline KK10 & & 0.762 & Valid \\
\hline KK11 & & 0.620 & Valid \\
\hline KK12 & & 0.581 & Valid \\
\hline & & & & \\
\hline
\end{tabular}

Sumber: Data yang telah diolah (2020)

Berdasarkan Tabel 1 Hasil Uji Validitas terlihat bahwa variabel lingkungan fisik, lingkungan non fisik, dan kinerja karyawan menunjukkan hasil yang signifikan yaitu nilai pearson correlation $>0.3$. Sehingga dapat disimpulkan bahwa seluruh item variabel tersebut adalah valid.

Suatu instrumen penelitian dapat dikatakan reliabel jika jawaban terhadap suatu pernyataan konsisten atau stabil dari waktu ke waktu. Pengujian reliabilitas instrumen (alat ukur) penelitian dapat dilakukan dengan menggunakan rumus Alpha Cronbach. Apabila instrumen memiliki koefisien keandalan reliabilitas sebesar lebih dari 0,6 maka instrumen tersebut dapat dikatakan reliabel. 
Tabel 2

Hasil Koefisien Reliabilitas

\begin{tabular}{ccc}
\hline Variabel & Cronbach's Alpha & Keterangan \\
\hline LF & 0.744 & Reliabel \\
\hline LNF & 0.756 & Reliabel \\
\hline KK & 0.879 & Reliabel \\
\hline
\end{tabular}

Sumber: Data yang telah diolah (2020)

Berdasarkan pada Tabel 2 Hasil Koefisien Reliabilitas, dapat dilihat bahwa seluruh variabel melebihi batas kriteria reliabilitas yakni 0.6, sehingga seluruh variabel tersebut memenuhi kriteria Cornbach's Alpha dan dapat dinyatakan bahwa keseluruhan item reliabel.

\section{b. Analisis Statistik Penelitian}

\section{Uji normalitas}

Uji normalitas dilakukan dengan test Kolmogorov-Smirnov yang bertujuan untuk mengetahui apakah data dalam variabel yang akan dianalisis berdistribusi normal atau tidak (Irvan, 2016).

Tabel 3

Hasil Uji Normalitas

\begin{tabular}{|c|c|c|}
\hline \multicolumn{3}{|c|}{ One-Sample Kolmogorov-Smirnov Test } \\
\hline \multicolumn{3}{|c|}{ Unstandardized Residua } \\
\hline $\mathrm{N}$ & & 54 \\
\hline \multirow[t]{2}{*}{ Normal Parameters ${ }^{\mathrm{a}, \mathrm{b}}$} & Mean & .0000000 \\
\hline & Std. Deviation & 3.11666658 \\
\hline \multirow[t]{3}{*}{ Most Extreme Differences } & Absolute & .100 \\
\hline & Positive & .096 \\
\hline & Negative & -.100 \\
\hline Kolmogorov-Smirnov Z & & .735 \\
\hline Asymp. Sig. (2-tailed) & & .652 \\
\hline a. Test distribution is Norr & & \\
\hline
\end{tabular}

Sumber: Data yang telah diolah (2020)

Hasil uji normalitas pada tabel diatas menunjukkan bahwa nilai asymp sig yang diperoleh sebesar 0.652. Nilai ini lebih besar dibandingkan tingkat signifikansi yang digunakan yaitu 0.05. Berdasarkan kriteria uji normalitas, dapat disimpulkan bahwa data berdistribusi normal.

\section{Uji Multikolinieritas}

Pengujian Multikolinieritas digunakan untuk menunjukkan adanya korelasi atau hubungan antara dua variabel bebas atau lebih dalam model penelitian regresi berganda (Ghozali, 2009). 
Tabel 4

Hasil Uji Multikolinearitas

\begin{tabular}{|c|c|c|c|c|c|c|c|c|}
\hline \multirow{3}{*}{\multicolumn{2}{|c|}{ Model }} & \multicolumn{5}{|c|}{ Coefficients $^{\mathrm{a}}$} & \multirow{2}{*}{\multicolumn{2}{|c|}{$\begin{array}{c}\text { Collinearity } \\
\text { Statistics }\end{array}$}} \\
\hline & & \multicolumn{2}{|c|}{$\begin{array}{l}\text { Unstandardized } \\
\text { Coefficients }\end{array}$} & \multirow{2}{*}{$\begin{array}{c}\text { Standardized } \\
\text { Coefficients } \\
\text { Beta }\end{array}$} & \multirow[t]{2}{*}{$\mathrm{t}$} & \multirow[t]{2}{*}{ Sig. } & & \\
\hline & & B & Std. Error & & & & Tolerance & VIF \\
\hline \multirow[t]{3}{*}{1} & (Constant) & 18.032 & 4.365 & & 4.131 & .000 & & \\
\hline & LF & .406 & .142 & .388 & 2.858 & .006 & .721 & 1.387 \\
\hline & LNF & .569 & .299 & .258 & 1.902 & .063 & .721 & 1.387 \\
\hline
\end{tabular}

Sumber: Data yang telah diolah (2020)

Tabel 4 diatas menunjukkan bahwa variabel LF dan LNF memiliki nilai tolerance lebih besar dari 0.1 dan nilai VIF lebih kecil dari 10, sehingga dapat disimpulkan bahwa tidak ada multikolinearitas dalam model regresi.

\section{Uji Heteroskedastisitas}

Menurut (Ghozali, 2009) uji heteroskedastisitas ini dilakukan untuk menguji adanya ketidaksamaan variance dari residual satu pengamatan ke pengamatan yang lain dalam model penelitian regresi.

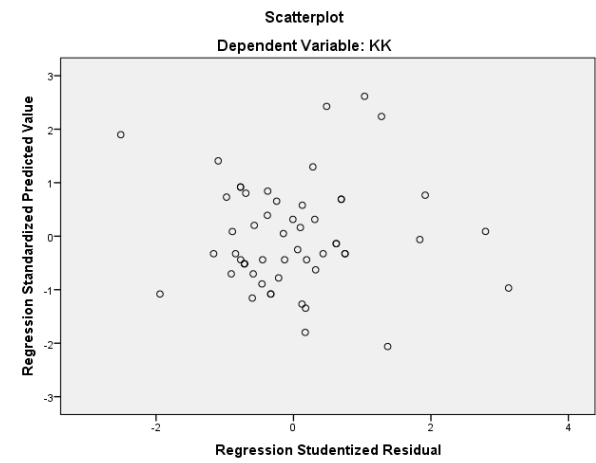

\section{Gambar 1 \\ Hasil Uji Heteroskedastisitas}

Sumber: Data yang telah diolah (2020)

Gambar diatas menunjukkan bahwa grafik scatterplots terlihat titik - titik menyebar secara acak serta tersebar baik di atas maupun di bawah angka 0 pada sumbu Y, sehingga dapat disimpulkan bahwa tidak terjadi heteroskedastisitas pada model regresi, sehingga model regresi layak untuk dipakai.

\section{Uji Regresi Linier Berganda}

(Ghozali, 2009) menjelaskan bahwa metode analisis regresi linier berganda adalah metode statistik yang digunakan untuk mengetahui hubungan fungsional diantara variabel independen (bebas) dengan variabel dependen (terkait). 


\section{Tabel 5}

Tabel Coefficients Regresi Linier Berganda

\begin{tabular}{|c|c|c|c|c|c|}
\hline \multirow{3}{*}{ Model } & \multicolumn{4}{|c|}{ Coefficients $^{\mathrm{a}}$} & \multirow{3}{*}{ Sig. } \\
\hline & Unstandardi & Coefficients & Standardized Coefficients & $\mathrm{t}$ & \\
\hline & $\mathrm{B}$ & Std. Error & Beta & & \\
\hline (Constant) & 18.032 & 4.365 & & 4.131 & .000 \\
\hline LF & .406 & .142 & .388 & 2.858 & .006 \\
\hline LNF & .569 & 299 & .258 & 1.902 & .063 \\
\hline
\end{tabular}

a. Dependent Variable: KK

Sumber: Data yang telah diolah (2020)

Berdasarkan tabel 5, dapat diperoleh persamaan regresi sebagai berikut:

$$
\mathrm{Y}=18.032+0.406 \mathrm{X}_{1}+0.569 \mathrm{X}_{2}+e
$$

$\mathrm{Y}=$ Kinerja Karyawan

$\mathrm{X}_{1}=$ Lingkungan Fisik

$\mathrm{X}_{2}=$ Lingkungan Non Fisik

$e=$ error

Dimana:

$a=18.032$ artinya jika nilai lingkungan fisik dan lingkungan non fisik sama dengan nol, maka kinerja karyawan sama dengan 18.032.

b1 $=0.406$ artinya jika variabel lingkungan fisik meningkat sebesar satu satuan, maka kinerja karyawan meningkat sebesar 0.406.

b2 $=0.569$ artinya jika variabel lingkungan non fisik meningkat sebesar satu satuan, maka kinerja karyawan meningkat sebesar 0.569 .

\section{Uji Hipotesis Penelitian}

a) Uji $\mathrm{T}$ digunakan untuk menguji tingkat signifikan pengaruh variabel independen secara parsial (masing-masing) terhadap variabel dependen (Ghozali, 2009). Hipotesis yang diuji adalah :

- $H_{O}=\beta 1=0$ tidak terdapat pengaruh signifikan antara variabel lingkungan fisik $\left(\mathrm{X}_{1}\right)$ terhadap variabel kinerja karyawan $(\mathrm{Y})$.

- $\quad H_{1}=\beta 1 \neq 0$ terdapat pengaruh signifikan antara variabel lingkungan fisik $\left(\mathrm{X}_{1}\right)$ terhadap variabel kinerja karyawan $(\mathrm{Y})$.

- $H_{o}=\beta 2=0$ tidak terdapat pengaruh signifikan antara variabel lingkungan non fisik $\left(\mathrm{X}_{2}\right)$ terhadap variabel kinerja karyawan $(\mathrm{Y})$.

- $\quad H_{1}=\beta 2 \neq 0$ terdapat pengaruh signifikan antara variabel lingkungan non fisik $\left(\mathrm{X}_{2}\right)$ terhadap variabel kinerja karyawan $(\mathrm{Y})$.

Dari hasil uji pada Tabel 5 Dapat dilihat bahwa variabel lingkungan fisik dari hasil uji tersebut memiliki nilai Sig sebesar 0.006, artinya nilai tersebut lebih kecil dari alfa yang digunakan yaitu 0.05, dan dapat disimpulkan Ho ditolak sehingga variabel lingkungan fisik memiliki pengaruh terhadap kinerja 
karyawan. Sedangkan nilai Sig lingkungan non fisik memiliki nilai sebesar 0.063 nilai ini lebih besar dari alfa yang digunakan yaitu 0.05 , maka dapat disimpulkan Ho diterima sehingga tidak terdapat pengaruh lingkungan non fisik terhadap kinerja karyawan.

\section{Tabel 6}

Correlations Regresi Linier Berganda

\begin{tabular}{llrrr}
\hline \multicolumn{5}{l}{ Correlations } \\
\hline & \multicolumn{1}{c}{ KK } & \multicolumn{1}{c}{ LF } & LNF \\
\hline Pearson Correlation & KK & 1.000 & .524 & .463 \\
\cline { 2 - 5 } & LF & .524 & 1.000 & .528 \\
\cline { 2 - 5 } & LNF & .463 & .528 & 1.000 \\
\hline Sig. (1-tailed) & KK &. & .000 & .000 \\
\cline { 2 - 5 } & LF & .000 &. & .000 \\
\cline { 2 - 5 } & LNF & .000 & .000 &. \\
\hline $\mathrm{N}$ & KK & 54 & 54 & 54 \\
\cline { 2 - 5 } & LF & 54 & 54 & 54 \\
\cline { 2 - 5 } & LNF & 54 & 54 & 54 \\
\hline
\end{tabular}

Sumber: Data yang telah diolah (2020)

Berdasarkan Tabel 6 dapat diketahui besarnya pengaruh secara parsial. Besarnya pengaruh secara parsial dari variabel lingkungan fisik terhadap kinerja karyawan dengan nilai koefisien determinasi:

$\mathrm{Kd}=\mathrm{r}^{2} \times 100 \%$

$\mathrm{Kd}=0.524^{2} \times 100 \%=27.46 \%$. Artinya, dimana variabel lingkungan fisik mempengaruhi kinerja karyawan sebesar $27.46 \%$.

Hal ini sejalan dengan penelitian yang dilakukan oleh (Rorong, 2016) dan (Putra, 2013) yang menyatakan bahwa lingkungan kerja fisik memiliki pengaruh yang signifikan dan positif terhadap kinerja karyawan. Apabila keadaan sekitar lingkungan fisik tempat yang ditinggali sekarang baik itu rumah atau kos-kosan, memiliki penerangan, temperatur, sirkulasi udara, kebisingan, keamanan, dan keadaan fisik lainnya yang menunjang dan dalam kondisi yang baik, maka kinerja karyawan customer care yang melayani keluhan konsumen/pengguna pun juga akan bertambah baik sebesar 27,46\%.

Sedangkan untuk variabel lingkungan non fisik terhadap kinerja karyawan tidak dihitung besar pengaruh parsialnya karena tidak memiliki pengaruh secara parsial. Hal ini menunjukkan bahwa secara parsial lingkungan non fisik yang merupakan hubungan antara karyawan dengan atasannya ataupun dengan rekan kerjanya saat melakukan work from home tidak memberikan pengaruh terhadap kinerja karyawan customer care dalam memberikan pelayanan terhadap keluhan konsumen. 
b) Uji $\mathrm{F}$ digunakan untuk menguji tingkat signifikasi dari pengaruh variabel indepeden secara serempak terhadap variabel dependen. Hipotesis yang diuji adalah :

- $H_{o}=\beta 1$ dan $\beta 2=0$

maka tidak terdapat pengaruh signifikan antara variabel lingkungan fisik $\left(\mathrm{X}_{1}\right)$ dan lingkungan non fisik $\left(\mathrm{X}_{2}\right)$ terhadap kinerja karyawan $(\mathrm{Y})$.

- $\quad H_{1}=\beta 1$ dan $\beta 2 \neq 0$

terdapat pengaruh signifikan antara variabel budaya organisasi organisasi $\left(\mathrm{X}_{1}\right)$ dan komitmen organisasi $\left(\mathrm{X}_{2}\right)$ terhadap kinerja karyawan $(\mathrm{Y})$.

Tabel 7

ANOVA Uji t Regresi Linier Berganda

\begin{tabular}{llrrrrr}
\hline \multicolumn{7}{c}{ ANOVA $^{\mathrm{a}}$} \\
\hline Model & Sum of Squares & df & Mean Square & F & Sig. \\
\hline \multirow{2}{*}{1} & Regression & 245.493 & 2 & 122.747 & 12.160 & $.000^{\mathrm{b}}$ \\
\cline { 2 - 7 } & Residual & 514.821 & 51 & 10.095 & & \\
\cline { 2 - 7 } & Total & 760.315 & 53 & & & \\
\hline
\end{tabular}

a. Dependent Variable: KK

b. Predictors: (Constant), LNF, LF

Sumber: Data yang telah diolah (2020)

Hasil pengolahan regresi variabel lingkungan fisik dan lingkungan non fisik terhadap kinerja karyawan dapat dilihat pada tabel diatas. Berdasarkan tabel ANOVA, nilai Sig. yang diperoleh adalah sebesar 0.000. Nilai ini lebih kecil dibandingkan tingkat signifikansi yang digunakan yaitu 0.05 , artinya $\mathrm{H}_{0}$ ditolak sehingga dapat disimpulkan bahwa secara bersama-sama atau secara simultan variabel lingkungan fisik dan lingkungan non fisik berpengaruh terhadap kinerja karyawan.

Tabel 8

Model Summary

Model Summary

\begin{tabular}{lcccr}
\hline \multicolumn{5}{c}{ Model Summary } \\
\hline Model & R & R Square & $\begin{array}{c}\text { Adjusted R } \\
\text { Square }\end{array}$ & $\begin{array}{l}\text { Std. Error of } \\
\text { the Estimate }\end{array}$ \\
\hline 1 & $.568^{\mathrm{a}}$ & .323 & .296 & 3.17719 \\
\hline a. Predictors: (Constant), LNF, LF & & \\
\hline
\end{tabular}

Sumber: Data yang telah diolah (2020)

Dilihat dari Tabel 8 secara simultan lingkungan fisik dan lingkungan non fisik terhadap kinerja karyawan sebesar 0.296 atau 29.6\%. Hal ini sejalan dengan penelitian yang dilakukan oleh (Rorong, 2016), (Putra, 2013), (Lestary \& Chaniago, 2017) yang menyatakan bahwa lingkungan kerja memengaruhi kinerja karyawan customer care dalam pelaksanaan Work From Home (WFH) dalam bentuk pencegahan penyebar luasan Covid-19. Namun, pengaruh yang diberikan lingkungan kerja ini tidak cukup besar. 
Sebesar 70,4\% variabel lain dapat memberikan pengaruh namun tidak dijelaskan dalam penelitian ini, seperti kepemimpinan, kompensasi, motivasi kerja, dan lain sebagainya.

\section{Kesimpulan}

Lingkungan fisik memiliki pengaruh secara parsial terhadap kinerja karyawan customer care Bidang Kesehatan X sebesar 27,46\%. Hal ini menunjukkan bahwa lingkungan fisik para karyawan yang bekerja sebagai customer care saat menjalankan WFH, baik itu di kos-kosan, rumah tinggal bersama keluarga ataupun pribadi memengaruhi hasil kerja ataupun output yang mereka keluarga dalam rangka memenuhi tugas dan tanggung jawab yang diberikan perusahaan. Lingkungan fisik yang dapat menjadi faktor-faktor yang berpengaruh terhadap kinerja karyawan ini antara lain penerangan, temperature, kelembaban udara, sirkulasi udara, kebisingan, getara mekanis, bau-bauan di area rumah, tata warna, dekorasi, musik, hingga keamanan tempat kerja. Hal-hal ini memiliki pengaruh naun dalam persentase yang kecil yang dimana cukup dapat digunakan sebagai bahan pengkajian bagi perusahaan.

Lingkungan non-fisik secara parsial tidak memiliki pengaruh terhadap kinerja karyawan yang bekerja sebagai customer care. Hal ini menunjukkan bahwa keadaan atau suasana kerja terkait hubungan atau komunikasi para karyawan customer care dengan atasan atau rekan kerja saat menjalankan WFH tidak mempengaruhi kinerja karyawan dalam bekerja.

Pengaruh lingkungan fisik dan non-fisik terhadap kinerja karyawan customer care di Bidang Kesehatan X diketahui terdapat nilai Sig diperoleh adalah sebesar 0.000. Nilai ini lebih kecil dibandingkan tingkat signifikansi yang digunakan yaitu 0.05 , artinya $\mathrm{H} 0$ ditolak sehingga dapat disimpulkan bahwa secara bersama-sama atau secara simultan variabel lingkungan fisik dan lingkungan non fisik para karyawan selama WFH berpengaruh terhadap kinerja karyawan customer care dalam melayani keluhan dan memberikan informasi kepada kosumen. Besarnya pengaruh yang diberikan sebesar $29,6 \%$. 
Irene Melati Carlita, Arshad Rahmanidal dan Sedarmayanti

\section{BIBLIOGRAFI}

Cooper, Donald R., \& Schindler, Pamela S. (2006). Metode riset bisnis. Jakarta: PT Media Global Edukasi. Google Scholar

Ghozali, I. (2009). Aplikasi Analisis Multivariate dengan Program SPSS. Semarang: Penerbit Universitas Dipenogoro. Google Scholar

Irvan, Muhammad. (2016). Pengaruh Budaya Organisasi dan Kepemimpinan Transformasional terhadap Employee engagement pada Karyawan PT " $X$ " Bandung. Universitas Kristen Maranatha. Google Scholar

Lestary, Lyta, \& Chaniago, Harmon. (2017). Pengaruh Lingkungan Kerja Terhadap Kinerja Karyawan. Jurnal Riset Bisnis Dan Investasi, 3(2), 94-103. Google Scholar

Mangkunegara, A. A. Anwar Prabu. (2016). Manajemen sumber daya manusia perusahaan. PT. Remaja Rosdakarya. Google Scholar

Nitisemito, Alex S. (1982). Manajemen personalia:(Manajemen sumber daya manusia). Ghalia Indonesia. Google Scholar

Organization, World Health. (2020). Naming the coronavirus disease (COVID-19) and the virus that causes it. Google Scholar

Putra, Fariz Ramanda. (2013). Pengaruh Lingkungan Kerja Terhadap Kinerja (Studi Pada Karyawan PT. Naraya Telematika Malang). Jurnal Administrasi Bisnis, 6(1). Google Scholar

Rorong, Syutrika Vergie. (2016). The impact of physical work environment toward employee performance at PT. Bank Negara Indonesia Manado Regional Office. Jurnal EMBA: Jurnal Riset Ekonomi, Manajemen, Bisnis Dan Akuntansi, 4(1). Google Scholar

Sedarmayanti. (2011). Tata Kerja dan Produktivitas Kerja (Suatu Tinjauan Dari Aspek Ergonomi Atau Kaitan Antara Manusia Dengan Lingkungan Kerjanya). Bandung: Penerbit Mandar Maju.

Sedarmayanti. (2013). Manajemen Sumber Daya Manusia. Bandung: PT Refika Aditama.

Sedarmayanti. (2016). Manajemen Sumber Daya Manusia Reformasi Birokrasi dan Manajemen. Google Scholar

Sedarmayanti. (2017). Manajemen Sumber Daya Manusia Reformasi Birokrasi dan Manajemen Pegawai Negeri Sipil. Bandung: PT Refika Aditama.

Soekanto, Sugiyono. (2007). Statistika Untuk Penelitian. Bandung: Alfabeta. Risk 
Pengaruh Lingkungan Kerja terhadap Kinerja Customer Care yang Menerapkan Work from Home Di Bidang Kesehatan

Perception Pada Pengambilan Keputusan Investasi. Journal of Business and Banking, 4(1), 55-66. Google Scholar

\section{Copyright holder:}

Irene Melati Carlita, Arshad Rahmanidal dan Sedarmayanti (2021)

First publication right:

Journal Syntax Literate

This article is licensed under:

(c) ()$_{\mathrm{EY}} \ominus$ 